Јована Прокопијевић

(Филозофски факултет, Нови Сад)
Изворни научни рад

УДК 821.163.41.09 Andrić I.

DOI 10.19090/ppj.2020.51.207-225

\title{
УТВРЪИВАЮЕ АУТОРСТВА И. АНДРИЋА У СПОРНИМ ТЕКСТОВИМА ОБЈАВЉЕНИМ У ЧАСОПИСУ СВЕСКЕ ЗАДУЖБИНЕ ИВЕ АНДРИЋА (БРОЈЕВИ 16 И 17) ${ }^{1}$
}

\begin{abstract}
САЖЕТАК
Предмет овог рада је утврђивање ауторства Иве Андрића у спорним текстовима који су објављени у часопису Свеске Задужбине Иве Андрића путем утврђивања језичких и стилских маркера. У раду је анализиран синтаксички ниво језика у спорним и познатим текстовима Ива Андрића. Циљ рада је да се утврде сличности и разлике у језику и стилу познатих Андрићевих текстова и спорних рукописа објављених у часопису, на основу којих износимо мишљење о могућности ауторства Ива Андрића у спорним текстовима. Истраживање је базирано на грађи ексцерпираној из шест спорних рукописа и из осам познатих Андрићевих текстова. Грађи се приступа као стилским маркерима који одређују једног аутора и дају нам информације о њему, његовом језику и стилу. Сагледавање и анализа грађе дали су нам јасну слику о језику и стилу Ива Андрића, као и о језику и стилу спорних текстова. Њиховим компарирањем осветљено је питање Андрићевог ауторства у спорним текстовима.
\end{abstract}

КљУЧНЕ РЕЧИ: форензичка лингвистика, утврђивање ауторства, језички и стилски маркери, спорни рукописи, стил.

\section{1. Увод}

\section{1. О спорним рукописима}

Након смрти Иве Андрића 1975. године, међу његовом многобројном рукописном заоставштином пронађена је и кутија с исписаним папирима и свескама. На једној од свезака, за коју се сматра да је настала негде током

\footnotetext{
${ }^{1}$ Рад представља скраћену и прилагођену верзију мастерског рада одбрањеног 2020. године на Филозофском факултету у Новом Саду, а рађен је под менторством доц. др Јелене Редли.
} 
1928/29. године, стајало је написано „Спалити неотворено моје приватно“. Међутим, комисија која је пописивала пишчеву заоставштину одлучила је да кутију запечати и сачува све до 2000. године када је требало да буде отпечаћена.

Пуне 24 године ова кутија с рукописима уредно је чувана у Архиву САНУ. Године 1999, због рата који је у Србији био у току, Управни одбор Андрићеве задужбине одлучио је да кутија раније буде отпечаћена. Након тога, рукописи су даље предати на старање и обраду академику Предрагу Палавестри, потпредседнику Задужбине, који је ангажовао др Биљану Сикимић, из Института за српски језик САНУ, и Зорана Живковића, из Архива САНУ, како би израдили аналитички инвентар, дешифровали и прекуцали ову рукописну грађу.

Обрађени и сређени рукописи објављени су у часопису Свеске који издаје Задужбина Иве Андрића у бројевима 16 и 17 (март и октобар 2000. године) у рубрици Рукописи из кутије. Након њиховог објављивања, многи књижевни критичари, професори и познаваоци Андрићевог дела, као што су Мирослав Караулац, Жанета Ђукић Перишић, Душан Иванић и Небојша Грујичић, увидели су да се ти текстови, језички, стилски, али и по тематици којом се баве, у великој мери разликују од познатог пишчевог опуса. У недељнику Време (број 526), Мирослав Караулац, један од највећих познавалаца Андрићевог књижевног дела, изнео је одређене доказе да спорни текстови нису Андрићеви, већ да је њихов аутор Драгомир Јанковић (1867-1942), некадашњи драматург Народног позоришта у Београду. Он је у једном тексту који је објављен у часопису Време (22. фебруар 2001. године) истакао да су делови Дневника Самуила Фаја били објављени у књижевном листу Српски преглед још 1895. године под именом Драгомира Јанковића, дакле, 105 година пре него што ће се делови тог дневника наћи у часопису Свеске под Андрићевим именом. Предраг Палавестра, главни уредник часописа, након оваквих доказа повукао је рукописе из часописа и упутио извињење читаоцима.

\section{2. Предмет, задаци и циљеви истраживања}

Овај рад представља допринос утврђивању ауторства Иве Андрића у спорним текстовима у контексту форензичке лингвистике. Анализа стилских и језичких обележја спорних и познатих текстова представља предмет овог рада. На основу резултата добијених анализом врши се утврђивање 
ауторства Иве Андрића у спорним текстовима. Тим језичким и стилским обележјима приступа се као стилским маркерима који одређују једног писца и који ће допринети осветљавању питања ауторства. У самом раду извршена је компаративна анализа текстова с циљем да се утврде сличности и разлике између ова два типа текста са становишта форензичке лингвистике. Пре свега, анализиран је синтаксички ниво језика, при чему је пажња усмерена на састав и тип реченица, као и на различите поступке онеобичавања реченичне конструкције. Синтаксички ниво је најдубље похрањен у свести писца и веома га је тешко контролисати и мењати. Због тога је овај ниво и најзначајнији за истраживања форензичке лингвистике и утврђивање ауторства.

Циљ истраживања јесте да се резултати добијени компаративном анализом, са становишта форензичке лингвистике, упореде и да се изведу основни закључци о стилу и језичким карактеристикама оба типа текста. Затим, на основу тих закључака износи се мишљење о могућности ауторства Иве Андрића у спорним текстовима.

\section{3. Корпус истраживања}

Истраживање овог рада базира се на корпусу који чини грађа ексцерпирана из спорних рукописа пронађених у заоставштини Иве Андрића, као и грађа из његових познатих текстова. У корпус спорних рукописа спадају: Дневник Самуила Фаја, Моцарт, Расути листови, Вуле Пупавац, Поводом Коштане и Читајући Мередита. Све рукописе за штампу је приредила Биљана Сикимић, научни сарадник САНУ. Са друге стране, корпус познатих текстова чини осам текстова различитог жанра и године настанка. Четири таква текста објављена су постхумно у часопису Свеске, док су остала четири текста преузета из збирке приповедака Андрић: Приче (2017). Из часописа Свеске то су: приповетке Три дечака и Бракови, текст Къига необјављених текстова Виктора Ига, као и Андрићеве дневничке белешке из Берлина које носе назив Међу сиренама. Затим, из збирке Андрићевих прича приповетке Жеђ (1934), Бајрон у Синтри (1935), Децุа (1935) и Къига (1946). 


\section{4. Методологија истраживања}

Приликом овог истраживања определили смо се за компаративну анализу језика и стила у спорним и познатим текстовима. Метода компаративне анализе текстова састоји се у проналажењу сличности и разлика између два текстуална стила. Поређење и контрастирање представља процес идентификовања онога што је у структури текста исто или различито, односно испитивање стила спорних и познатих текстова у форензичком контексту (Nikolić Novaković 2017: 122).

Приликом анализе посматрали смо језичке карактеристике текста које сматрамо необичним, односно обележеним, а које су значајне за анализу језика и стила овог писца. Форензички лингвиста Џон Олсон сматра да је „za obeleženost važno da je to verzija nekog lingvističkog znaka ili strukture koja se ističe jer je na neki način neobična ili nestandardna“"(Olsson 2010: 56).

Из анализиране грађе у табеле нису унети сви примери одређених језичких или стилских карактеристика, већ само они за које смо сматрали да на најбољи начин осликавају посматрану карактеристику. Примере које смо ексцерпирали из анализиране грађе распоредили смо у табеле тако да се примери из спорних и примери из познатих текстова налазе једни наспрам других ради лакшег уочавања разлика. Након сваког примера у табели дате су скраћенице наслова текста и број стране са које је пример преузет.

\section{2. Компаративна анализа спорних и познатих текстова (синтаксички ниво)}

Синтакса је језички слој који је најдубље похрањен у свести човека, па је због тога најмање доступан свести писца и веома је тешко опонашати га. Због тога Џон Олсон сматра да је синтаксички језички слој најпогоднији за форензичка разматрања:

„Što je dublji sloj, manje je dostupan svijesti pisaca i teže ga je oponašati. To je u forenzičkom kontekstu prva utvrdila Chaski 1997. godine. ${ }^{2}$ Stoga je sintaksički sloj obično korisniji i važniji za forenzičke

\footnotetext{
${ }^{2}$ Керол Часки у свом раду из 1998. године (A Daubert-Inspired Assessment of Current Techniques for Language-Based Author Identification) истиче да је стварање синтаксичких структура веома тешко контролисати.
} 
svrhe nego što je ono što se može vidjeti u površinskim slojevima - npr. u pravopisu, izgledu dokumenta itd“(Olsson 2010: 53).

\section{1. Инверзија}

Под инверзијом подразумевамо обртање реда речи у реченици или делова реченице, односно онеобичавање распореда делова реченице. „Уколико се зависна реченица налази испред главне (управне) реченице, дакле у инверзији - запета се пише на њеном крају, испред главне реченице“ (Правопис српскога језика 2014: 113). Ово правописно и синтаксичко правило доследно је спроведено у познатим текстовима. У спорним текстовима оно није доследно спроведено, па проналазимо и примере у којима нема запете иза реченице у инверзији.

\begin{tabular}{|c|c|}
\hline Познати текстови & Спорни текстови \\
\hline $\begin{array}{l}\text { Кад су одједном почели да грувају топови } \\
\text { са тврђава које окружују Сарајево, уска } \\
\text { долина се испунила заглушним тутњем ... } \\
(\text { ТД, } 8)\end{array}$ & $\begin{array}{l}\text { Ако ко ушчита, дневник није исто као } \\
\text { кад би се слушао Fуе (ДСФ, 10) }\end{array}$ \\
\hline $\begin{array}{l}\text { Кад је таст умро, Зое, која је за свог оца } \\
\text { имала целог века неку чудну мешавину } \\
\text { нездравог обожавања и дивљег отпора, } \\
\text { пала је у меланхолију }(Б, 11)\end{array}$ & $\begin{array}{l}\text { Ако би се ствар популарисала, било би } \\
\text { упоредо са текстом ... }(\mathrm{M}, 64)\end{array}$ \\
\hline $\begin{array}{l}\text { Кад бих ноћас погинуо од једне од ових } \\
\text { граната што као танке лавине хуче } \\
\text { изнад мога крова, настрадао бих као глув } \\
\text { човек од трамваја ... (МС, } 62)\end{array}$ & $\begin{array}{l}\text { Ако му се не да израза игром глумчевом, } \\
\text { али потпуно на овом степену, окрњи се } \\
\text { улози значај ... (ВП, } 14)\end{array}$ \\
\hline $\begin{array}{l}\text { Кад се палба, после првог напада, } \\
\text { стишала, заспао сам оним топлим и } \\
\text { прозирним сном којим човек спава } \\
\text { између два буђења ... (МС, 62) }\end{array}$ & $\begin{array}{l}\text { Кад се узима лек, пази се и отварају очи } \\
\text {... (РЛ, 73) }\end{array}$ \\
\hline $\begin{array}{l}\text { Као и већина юегових вршњака, и он се } \\
\text { враћа тешка срца после дугих летњих } \\
\text { дана слободе ... (Књ, 304) }\end{array}$ & $\begin{array}{l}\text { Да је по мени, назвао бих књижицу } \\
\text { шапутањима тетке Злате ... }(\mathrm{K}, 25)\end{array}$ \\
\hline $\begin{array}{l}\text { Да би се лечио, Лазар је уз помоћ млађих } \\
\text { хајдука начинио [...] заклон од сухог } \\
\text { грања ... (Ж, 235) }\end{array}$ & $\begin{array}{l}\text { Да се себичњак могао продужити, } \\
\text { бесконачно продужити, лични је утисак } \\
\ldots(\text { (ЧМ, 32) }\end{array}$ \\
\hline $\begin{array}{l}\text { Чим су прошли капију парка, он је } \\
\text { напустио друштво (БуС, 241) }\end{array}$ & $\begin{array}{l}\text { Ако ко ушчита ову књижииу можда ће } \\
\text { разумети поруке ... (ДСФ, 9). }\end{array}$ \\
\hline
\end{tabular}


Да би издувао срибу, претрчавао је И ако сав нагнут на једну страну зна да басамаке одмахујући оном краћом, се кад тад мора исправити или по њему хромом ногом ... (БуС, 241) искривити ... $(К, 17)$

Иако је свитање освајало, жена није За оно што се зове трагичном кривицом имала снаге да се макне (Ж: 240) не треба више (ВП, 13)

На основу примера у табели можемо закључити да је инверзија чест стилски поступак и у спорним и у познатим текстовима. Разлика је у томе што се у спорним текстовима запета спорадично употребљава, као и у типу реченица које се налазе у инверзији. У спорним текстовима, у највећем броју случајева то су кондиционалне реченице, док су у познатим текстовима то темпоралне реченице с везником кад.

\section{2. Маркиране падежне конструкције}

У спорним текстовима наилазимо на одређене падежне конструкције које показују одступање од савремене језичке норме. Спорни текстови специфични су због употребе повратне личне заменице себе у одређеним падежним облицима. На основу примера које смо издвојили у табели, можемо закључити да аутор спорних текстова инструментал личне повратне заменице себе употребљава без предлога $c(a) / 3 a$ у конструкцијама са прелазним глаголима који означавају неко физичко померање ствари/предмета (однети, носити, повући итд.).

\begin{tabular}{cl}
\hline Познати текстови & \multicolumn{1}{c}{ Спорни текстови } \\
\hline$/$ & $\begin{array}{l}\text {... али сам га оба пута однео собом не остваривши га (ВП, } \\
9) .\end{array}$ \\
\hline$/$ & О. можда не би однео собом толико неисказаног ... (К, 22) \\
\hline$/$ & $\ldots$ (К, 22) \\
\hline$/$ & $\ldots$ али провидан и повукао собом $($ ЧМ, 33) \\
\hline$/$ & $\begin{array}{l}\text { Шта каже на ово све Goе који је ваљало да собом носи } \\
\text { кључ ... (ДСФ, 32) }\end{array}$ \\
\hline Стара се човек о себи, а повео би собом бродоломнике од \\
реда ... (ДСФ, 35) \\
\hline ... али би причувани хумор поврх таме дигао собом и нас \\
саморазмажене ... (М, 64)
\end{tabular}

У анализираним познатим текстовима нисмо пронашли примере овакве употребе повратне заменице себе. Конструкција с личном заменицом за 
свако лице себе у инструменталу представља разлику између спорних и познатих текстова.

2.3. Употреба личне заменице за треће лице једнине (он/оно)

$\mathrm{У}$ акузативу с предлозима за, $y$, на и пред(a), аутор спорних текстова користи облик личне заменице $ь$, уместо дужег облика њега, док у свим осталим случајевима користи наглашене облике у складу са савременом нормом. $^{3}$

\begin{tabular}{|c|c|}
\hline Познати текстови & Спорни текстови \\
\hline l & ... безмало сваки посепце и колико је издао за ғ $(\mathrm{BП,} 11)$ \\
\hline / & $\begin{array}{l}\text {... она је кадра осетити вазнесење, утопити се } y \text { н да је } \\
\text { подиђу жмарци и страва }(\kappa, 25)\end{array}$ \\
\hline / & ... он је имао снаге за њ и смелости, дрскости (ЧМ, 33) \\
\hline / & $\begin{array}{l}\text {... наишавши на њ у хрпи хартије и нешто књига ... (ДСФ, } \\
\text { 18) }\end{array}$ \\
\hline / & ... питање није постављало преда њ (ДСФ, 20) \\
\hline / & $\begin{array}{l}\text {... кад се заборави на живот или обрнуто: кад се подсети на } \\
\qquad b(\mathrm{M}, 65)\end{array}$ \\
\hline / & Фабрика, жрвањ, једина прилика за њ, грехота (РЛ, 74). \\
\hline
\end{tabular}

\section{4. Употреба запете међу деловима реченице}

Анализом спорних текстова дошли смо до закључка да у свим текстовима доследно изостаје запета приликом употребе модалних речи, односно не одвајају се запетом модалне речи и изрази. Модалним речима сматраћемо оне речи и изразе којима се исказује однос аутора према садржају реченице. Према Правопису Матице српске, оне се одвајају запетом увек када се осећају као коментар садржаја реченице у којој се налазе, односно када се

3 Овакве синтагме нису типичне за познате текстове. Анализирајући језик И. Андрића, Живојин Станојчић издваја акузативне синтагме с предлогом кроз(а). У делу Ex Ponto налазимо, на пример: Ja kro za nj prolazim kao kroz tamno zeleni mir $i$ mirisnu tišinu om orikove šume (ЕхР 1920, 27). Међутим, у овом случају конструкција кроз + краћи облик заменице у акузативу има значење кретања с једне на другу страну, кретање по горњој површини (Stanojс̌ić 1967: 114). У спорним текстовима не наилазимо на такво значење падежне конструкције. 
осећају као посебна интонациона целина (Правопис српског језика 2014: 102).

\begin{tabular}{|c|c|}
\hline Познати текстови & Спорни текстови \\
\hline $\begin{array}{l}\text {... правилним васпитањем или, напротив, } \\
\text { остаје у детету ... (КЮ, 304) }\end{array}$ & $\begin{array}{l}\text {.. ипак није доцкан, на против отпало је } \\
\text { оно што је мене уздржавало ... (ВП, } 9)\end{array}$ \\
\hline $\begin{array}{l}\text {... одмах утону у сан и непомичност; } \\
\text { напротив, сви они и тада учествују у } \\
\text { животу ... (ТД, } 10)\end{array}$ & $\begin{array}{l}\text {... на против прва му је дужност па и не } \\
\text { умео у почетку ... (ДСФ, } 33)\end{array}$ \\
\hline $\begin{array}{l}\text { У овим забелешкама има, наравно, и } \\
\text { таквих ... (КНТВИ, 10) }\end{array}$ & $\begin{array}{l}\text { Мeђутим има више, куд и камо више, } \\
\text { има побуне ... (ВП: } 13)\end{array}$ \\
\hline $\begin{array}{l}\text { И сви су, наравно, хвалили и жалили } \\
\text { мужа, а осуђивали сваком тешку и } \\
\text { непријатну жену (Б: 12). }\end{array}$ & $\begin{array}{l}\text { Ми међутим и гледаоци и учесници } \\
\text { бисмо да је мање лиричан ... (ЧМ, } 33)\end{array}$ \\
\hline $\begin{array}{l}\text {... најпосле, ево једна земља у којој је } \\
\text { самоћа весела (БуС, 241) }\end{array}$ & $\begin{array}{l}\text { Најзад врло је могуће да се у прпи } \\
\text { питање није постављало преда њ (ДСФ, } \\
\text { 20). }\end{array}$ \\
\hline $\begin{array}{l}\text { То су, дакле, те лепоте и та задовољства } \\
\text {... (КН, 307) }\end{array}$ & $\begin{array}{l}\text { Не веслати дакле већ скрстити руке у } \\
\text { чуну ... (ДСФ, 25) }\end{array}$ \\
\hline $\begin{array}{l}\text { А сад, ево, види како њему жандарми } \\
\text { враћају дуг (Ж, 239) }\end{array}$ & $\begin{array}{l}\text { На неким местима у Фигаровој свадби } \\
\text { на пример чини се, и лични утисак } \\
\text { износи се онакав какав је ... (M, } 65)\end{array}$ \\
\hline
\end{tabular}

Битну разлику између ова два типа текста представља начин писања модалне речи напротив, која изражава повезаност мисли. У познатим Андрићевим делима ова модална реч пише се састављено (напротив), док се у спорним текстовима ова реч увек пише растављено као две речи (на против).

\section{5. Запета иза везника на почетку реченице}

У познатим текстовима често долази до интерпункцијског издвајања везника на почетку реченице. Интерпункцијско издвајање делова реченице, у овом случају везника, служи за повезивање текста. Тако употребљен везник има, пре свега, функцију текстуалног конектора. То значи да се почетак реченице наслања на претходни текст и садржи елементе неопходне за кохезију текста (Ivanova 2012: 484). 


\begin{tabular}{lc}
\hline \multicolumn{1}{c}{ Познати текстови } & Спорни текстови \\
\hline Јер, он је изнутра сав био у пламену $($ БуС, 241$)$ & $/$ \\
\hline Јер, газда Перо воли да говори ... (ТД, 11$)$ & $/$ \\
\hline Али, као толико пута у животу ... (ТД, 8$)$ & $/$ \\
\hline Али, то је мағе важно (БуС, 242$)$ & $/$ \\
\hline Али, било да нас је одавао наш изглед ... (Д, 245) & $/$ \\
\hline Али, може ли тако вечно ићи (Ж, 239)? & $/$ \\
\hline
\end{tabular}

Одвајање везника на почетку реченице у функцији текстуалног конектора типично је за познате текстове. У спорним текстовима не проналазимо примере с оваквим издвајањем везника. Ова црта је нешто што је идиосинкратично за стил Ива Андрића јер је проналазимо у већини његових дела.

\section{6. Стилистика синтаксичких конструкција}

Андрић у својим делима употребљава различите синтаксичко-стилистичке поступке, којима се у свом раду бавила и Милка Николић (2012: 515). Она као најзаступљеније издваја интензивирање координативне конструкције, осамостаљивање појединих сегмената синтаксичког низа, изостављање конституената синтаксичке конструкције и пермутација, тј. промена уобичајеног распореда чланова линеарне синтаксичке структуре. Језик Ива Андрића веома је погодан за лингвостилистичку анализу. Сваки од ових поступака онеобичава уобичајене форме синтаксичких јединица. У наредном делу рада бавићемо се анализом само појединих поступака за које сматрамо да су најзначајнији за овај тип анализе и који представљају једну од главних карактеристика Андрићевог стила.

\subsection{1. Поступци интензивирања}

Поступком интензивирања одређени реченични члан на себе привлачи реченични акценат. Овај поступак остварује се понављањем односно редупликацијом пунозначних синтаксичких, али и релационих јединица. Интензивирање је језички поступак „преуређења синтаксичке конструкције којим се, употребом посебних формално-граматичких средстава, један или више реченичних чланова истиче (наглашава) и смисаоно и емфатички“ (Ковачевић 2000: 325). Поступке интензивирања, односно наглашавања проналазимо у свим текстовима. Међутим, разлика је у томе што тип 
интензивирања у познатим текстовима није исти као тип интензивирања у спорним текстовима.

\section{Познати текстови}

(1) Такво је било $и$ његово пословање $y$ трговини и његови поступции са људима, а нарочито у својој кући и са својима (ТД, 11)

(2) ... она је налазила $u$ пуну $u$ коначну потврду свих својих црних мисли ... (Б, 11)

(3) ... док не објави $u$ последюу реч $u$ последњи потез пера вољеног писца (КНТВИ, 11)

(4) И док су се још довршавали, мешали и сударали сви ти звукови, пресече $u$ оштро $u$ попреко, зујање првог енглеског авиона, реско, фино и упорно (МС: 63)

(5) $И$ сан $u$ храна јој се претворише у чекање ... (Ж, 235)

\section{Спорни текстови}

Ако је до происхођења, он би се могао ослонити на своје старо, прастаро колено, још чим су се двоје обрели на земљи (ВП, 11)

Он је обележен, преобележен $(К, 22)$
За пакост или за добро, јер ситна, преситна кадра је заменити велику силу ... (ДСФ, 50)

Није морао говорити ћутањем, тим својим ћутањем и гледањем испунио је прекид ... (ВП, 13)

... а како је у њему стално превирало и дубоко, врло дубоко, речи су му стојале недовољне ... $(\mathrm{K}, 16)$

(6) ... нису имали за мене ничег ни Призор је чест, врло чест ... (РЛ, 68) страшног ни узбудљивог (Д, 246)

(7) Има тачних $u$ нетачних, али увек ... да отвори очи и нереално доведе на моћних и блиставих слика читавих епоха чисто реално, страховито реално ... (РЛ, ... (КНТВИ, 11) 70)

(8) ... могло се наслутити да има потребу Нешто се од тог ужљеби, жаока, горчина, да са неким разговара још о животу $u$ нагриза живот, животић још из малена свету $и$ људима у њему $(5,11)$ ... (РЛ, 68)

(9) ... да је он сам некако мален $u$ збуњен $u$ неугледан (Књ, 304) ... он се кочио и укочио за ону ниансу која се осећа између музике ьегове и његовске ... $(\mathrm{M}, 67)$

(10) ... видео сам и чуо ьегов ударац и Локалне боје биле би у овом случају юегов узвик (Д, 245) ситан обзир, ситан да се просто и не помене (К, 23)

(11) Пред њим су се отварале све нове терасе, све нови путеви и све шири видик ... (БуС, 241)

... као на два иарства се ослони, два цчарства која се искључују ... (ДСФ, 10)

Примери ексцерпирани из познатих и спорних текстова обилују поступцима интензификације, међутим, можемо уочити да у већини примера то нису исти типови интензификације. 
У познатим текстовима највећи број примера илуструје тип интензификације редупликацијом координативног везника, односно редупликацијом релационих речи (Ковачевић 2000: 327). У тим случајевима координативни везник $и / н и$ налази се испред сваке од координираних јединица и, у том случају, добија и интензификаторску функцију. Овај случај илустрован је у примерима (1-6). У појединим примерима јавља се вишечлана координативна конструкција у којој се интензификатор $u$ не налази испред првог члана, „услед чега ће стилски потенцијал бити слабији. Међутим, везник $u$ се остварује испред свих осталих конституената - што омогућава да се постигне одређени стилски ефекат“ (Николић 2012: 517). Такав је случај и у примерима (7-9).

Примери (1), (3), (10) и (11) представљају интензификацију редупликовањем пунозначне синтаксичке јединице. У овим примерима редупликоване су присвојне заменице (юегови/юегов), придеви (последюи, све нови).

У примеру (7) видимо да улогу интензификатора може преузети и везник али. У овом случају копулативни везник $и$ замењује адверзативни везник али. „Употреба супротног (адверзативног) напоредног везника али омогућава да истицање одређеног дела исказа буде двоструко наглашеније, чему доприносе семантика везника и његова интензификаторска функција“ (Николић 2012: 517).

Интензивирање се у спорним текстовима, у највећем броју случајева, врши понављањем структурно неподударних синтаксичких јединица. Милош Ковачевић (2000: 326) овакво понављање назива епаналептичко понављағе, приликом којег поновљена јединица има сложенију синтаксичку структуру. Овај тип интензивирања проналазимо у скоро свим примерима. У примерима (1-3) интензивирање се врши понављањем јединице, при чему поновљена синтаксичка јединица добија префикс. Затим, интензивирање се врши додавањем показне и присвојне заменице поновљеној јединици (4), додавањем прилога и придева (5-7). Поновљена јединица може добити и одређене суфиксе као у примерима (8) и (9).

Већ смо навели да се интензивирање може вршити простим понављањем одређених језичких јединица. Такво понављање се назива епизеуксичко понављање, у коме се узастопце понавља хомоформна синтаксичка јединица синтаксема или синтагма (Ковачевић 2000: 325). Такав је случај са примерима (10) и (11). 


\subsection{2. Поступци пермутације}

Примери који следе показују да се у оба типа текста често јавља пермутација, односно ,језичко-стилски поступак измјештања језичке јединице из положаја који јој је предодређен у основној граматичко-семантичкој структури“ (Ковачевић 2000: 332). Дакле, под поступком пермутације подразумевамо онеобичавање распореда реченичних чланова, односно, онеобичавање уобичајене граматичке структуре. Постоји неколико типова пермутације, а у анализираним текстовима проналазимо неколико типичних примера.

\section{Познати текстови}

(1) Као што је дисање људско добро док нема потребе за лекаром $(Б, 9)$

(2) ... да га моли да једном речју својом, једним осмејком ... (Ж, 239)

(3) ... поглед му је пао на повијена плећа женина ... (Ж, 240)

(4) ... опет на нему заповед Милову ... (Д, 245)

(5) Са реке се јави кратко глас сирене са Реч ће произвести што јој је задано, али неког брода, промукао и слабачак (MC, се не осећа однос пишчев према речи ... 63)

(6) У висинама је још лебдела јека ... неизгладљивом пергаменту за повест сирене која је објавила поновну узбуну, родову (ЧМ, 32)

ублажена и далека (МС, 63)

(7) ... дешавало се чудо, истинско, ... издавач је видео да има пред собом необјашњиво и неописиво ... (БуС, 243) забелешке пријатељеве ... (ДСФ, 12)

(8) ... ми остали били смо војска, ... дао му веран смисао унутрашњи нестална и недисциилинована ... (Д, 244) (ДСФ, 18)

... да ни сам не зна каквим све порукама, ... оне нису оруђе спољно ... $(\mathrm{M}, 64)$ важним, лепим и занимљивим ... (Књ, 305)

\begin{tabular}{cl}
\hline$/$ & Да је једнако, јесте, још колико ... (ДСФ, \\
& $13)$ \\
\hline$/$ & Да је присвојио слободу, јесте, али пре \\
& теорисјку ... (ДСФ, 23) \\
\hline$/$ & $\begin{array}{l}\text { Да је промена, јесте, али све је то у њему } \\
\text { што се тада испољава (ВП, 13). }\end{array}$ \\
\hline
\end{tabular}

Поступком пермутације синтаксичка јединица добија статус синтаксостилема, јер долази до онеобичавања структурно-семантичке 
структуре реченице. У спорним текстовима преовладава тип пермутације у коме долази до премештања конгруентног атрибута у позицију иза супстантива. Конгруетни атрибут у основном граматичко-семантичком моделу реченице долази испред свог супстантива. Због тога конструкције с измештеним атрибутом сматрамо веома стилематичним. У познатим текстовима, такође се појављује овакав тип пермутације (1-5), али доста ређе него што је то случај са спорним текстовима. Оно што је типично за познате текстове јесте премештање конгруентних атрибута иза супстантива у финалну позицију (крај реченице) што уочавамо у примерима (5) и (6). Такође, типичне су и конструкције с два или више атрибута у позицији иза супстантива (7), (8) и (9), што није случај са спорним текстовима.

Перифрастичне глаголске структуре у којима се пермутује распоред непунозначног глагола и његове допуне дa + презент представља тип пермутације који се среће у спорним текстовима (10-12), док у анализираним познатим текстовима нисмо наишли на овакав тип пермутације.

\subsection{3. Бинарне конструкције}

Бинарна координативна синтаксичка конструкција је веома чест синтаксичко-стилистички поступак којим се Андрић служи у својим књижевним делима. Овакве координативне конструкције остварују се на различитим синтаксичким нивоима (Николић 2012: 522). Те бинарне конструкције одликују се одређеним стилским потенцијалом.

\begin{tabular}{|c|c|}
\hline Познати текстови & Спорни текстови \\
\hline $\begin{array}{l}\text { (1) Животно дело Виктора Ига, огромно } \\
\text { u разнолико, морало је као и свака } \\
\text { велика грађевина ... (КНТВИ, 10) }\end{array}$ & $\begin{array}{l}\text { Надстрешнице нема, самовольо } u \\
\text { обуздано, питомо и ћудљиво, котва } u \\
\text { заиграваье, смишьено и пусто, случај } u \\
\text { цһиљ ... (ДСФ, 46) }\end{array}$ \\
\hline $\begin{array}{l}\text { (2) Имао је лепу и рано увелу жену која } \\
\text { му је изродила десеторо деце ... (ТД, } 11)\end{array}$ & l \\
\hline $\begin{array}{l}\text { (3) Одјекују гласови непознатих } \\
\text { тропских животиња, крволочни и тужни } \\
\text { у исто време (MC, } 61)\end{array}$ & I \\
\hline $\begin{array}{l}\text { (4) ... док се у њега не мешају адвокати } \\
\text { u судије, црква и родбина }(5,9)\end{array}$ & / \\
\hline $\begin{array}{l}\text { (5) Чудно је било посматрати колико је } \\
\text { мрака и јада, сумье и сарказма излазило }\end{array}$ & / \\
\hline
\end{tabular}


из тог огромног тела $(Б, 11)$

(5) ... свега стотињак корака од мога прозора, гакање и писка перади и птица (MC, 61)

(6) ... говори о његовим пролазним сусретима и тренутним помислима, сновима и лутањима, дометима $u$ замрачењима (КНТВИ, 10)

Бинарне конструкције типичан су стилски поступак у познатим Андрићевим текстовима, док се у спорним текстовима појављује само један такав пример. У неким примерима јавља се по једна бинарна координативна конструкција (1-3). Најчешће се у језику и стилу Ива Андрића појављују примери с више напоредних конструкција (4-7). Бинарне конструкције имају значајну улогу у осликавању одређених појединости. На неки начин, оне означавају постојање два паралелна света.

\section{3. Закључна разматрања}

На крају овог рада указаћемо на резултате до којих смо дошли путем спроведене форензичколингвистичке анализе текстова. С обзиром на то да је циљ рада био утврђивање ауторства Ива Андрића у спорним текстовима који су објављени у часопису Свеске Задужбине Ива Андрића, било је неопходно одредити корпус познатих текстова с којима ћемо упоредити језичке карактеристике спорних текстова. На основу корпуса спорних и познатих текстова спроведена је компаративна анализа синтаксичког језичког нивоа, који је најдубље похрањен у свести писца, због чега га је тешко имитирати и мењати, а који је, самим тим, и најпоузданији показатељ ауторства. На овом плану уочене су неке сличности, али и многобројне разлике између спорних и познатих текстова.

Најчешћи поступак онеобичавања језичке структуре, у оба типа текста, јесте инверзија. Разлика је у томе што у познатим текстовима аутор доследно клаузу одваја запетом, док у спорним текстовима то није увек случај. Често се у спорним текстовима могу уочити реченичне конструкције у инверзији где су клаузе у препонованом положају у односу на главне реченице које нису одвојене запетама.

На синтаксичком плану проналазимо неке падежне конструкције којих нема у познатим текстовима. У спорним текстовима се доследно 
употребљава инструментал личне повратне заменице себе без предлога $c(a) / 3 a$ у конструкцијама с прелазним глаголима који означавају неко физичко померање ствари/предмета. Затим, лична заменица за треће лице једнине он/оно у конструкцији у акузативу с предлозима за, у, на и пред(a) доследно се употребљава у енклитичком облику њ.

Употребу интерпункцијских знакова посматрали смо у склопу синтаксичке анализе. Највећу разлику на овом плану представља употреба запете на почетку реченице иза везника, што је идиосинкратично за стил Иве Андрића. У спорним текстовима не проналазимо примере овакве употребе везника и запете.

Приликом анализе синтаксе, пажњу смо посветили и стилистици синтаксичких структура. Многи проучаваоци Андрићевог језика и стила слажу се у томе да Андрићев стил карактерише употреба бинарних конструкција, поступака пермутације и интензивирања. Анализом оба типа текста утврдили смо да се бинарне конструкције не појављују у спорним текстовима, осим једног изолованог примера. Поступци интензивирања појављују се у оба типа текста, с том разликом што је у спорним текстовима увек у питању интензивирање простим понављањем неке речи или понављање приликом којег поновљена синтаксичка јединица има сложенију структуру, и то додавањем префикса, суфикса, употребом деминутива итд. У познатим текстовима највећи број примера илуструје тип интензификације редупликацијом координативног везника. Поступци пермутације чест су стилски поступак како у спорним тако и у познатим текстовима. Анализом примера ексцерпираних из оба типа текста дошли смо до закључка да перифрастичне глаголске структуре у којима се пермутује распоред непунозначног глагола и његове допуне $\partial a+$ презент представљају тип пермутације који се среће у спорним текстовима, док у познатим текстовима нисмо наишли на пример оваквог типа пермутације.

\section{1. Мишљење}

На крају, на основу свега наведеног и на основу стилских маркера које смо издвојили и анализирали у главном делу овог рада, можемо дати своје мишљење о језику и стилу познатих и спорних текстова. Андрићев језички израз у складу је с основама језика књижевне норме коју је Вук Караџић установио. Његов доминантан стилски поступак је дескрипција, али тако да се у дескрипцији не оде у превелику ширину. За његов језик може се рећи да 
је веома сликовит, а његова реченица класична, што одговара свету који он описује и доноси читаоцима. Свако његово дело је дело високе уметничке вредности, што доказује и Нобелова награда за књижевност 1961. године. Његова лексика и дијалекат на коме пише откривају духовно тло с којег је Андрић поникао као писац и упућују на традицију која га је обликовала. С друге стране, имамо спорне текстове у којима има веома мало од свега онога што представља Андрићев књижевни израз. Текстови су написани стилом који карактерише архаична лексика, синтаксичке конструкције и спојеви речи који одударају од Андрићевог стила. Ови рукописи обилују „архаичном лексиком и отежалим стилским фигурама, из других књижевних школа, других времена и других животних прилика, неспојиви су, у свакој својој реченици, с Андрићевим књижевним изразом“" (Караулац 2006: 133).

На самом крају, на основу анализе стилских маркера ексцерпираних из спорних текстова и њиховим компарирањем са стилским маркерима у познатим текстовима, сматрамо да су разлике између спорних и познатих текстова Иве Андрића евидентне. Иако је графоскопском анализом утврђено да је спорни текст Коштана писан Андрићевом руком, разлике на плану синтаксе, лексике, стила многобројније су у односу на њихове сличности. Стога износимо мишљење да Иво Андрић највероватније није аутор спорних текстова. Остаје отворено питање рукописа - да ли је Андрић преписивач текстова или је у питању нешто друго.

„Остаје отворено питање: откуда рукописи Драгомира М. Јанковића у оставштини Иве Андрића; ко је био Драгомир М. Јанковић; када су, како и због чега Иви Андрићу поверени на чување Јанковићеви рукописи и бележнице који су нађени у Андрићевој заоставштини; какви су били њихови међусобни лични односи; зашто су једино ти рукописи после Андрићеве смрти комисијски запечаћени са налогом да се не отварају следећих 25 година?““ (Палавестра 2001: 277). 


\section{ИЗ В О Р И}

Андрић, Иво (1997). Три дечака. „Свеске” Задужбине Иве Андрића (свеска 13), 7-15. Андрић, Иво (1992). Бракови. „Свеске” Задужбине Иве Андрића (свеска 8), 9-12.

Андрић, Иво (2010). Кюига необјављених текстова Виктора Ига. „Свеске” Задужбине Иве Андрића (свеска 27), 10-12.

Андрић, Иво (2011). Међу сиренама. „Свеске” Задужбине Иве Андрића (свеска 28), $57-64$.

Андрић, Иво (2000). Рукописи из кутије: Дневник Самуила Фаја, Моиарт, Расути листови. „Свеске” Задужбине Иве Андрића (свеска 16), 7-74.

Андрић, Иво (2000). Рукописи из кутије: Вуле Пупаваџ, Коштана, Читајући Мередита. „Свеске” Задужбине Иве Андрића (свеска 17), 7-36.

Свеске Задужбине Иве Андрића (2001). Број 18. Београд: Задужбина Иве Андрића.

Andrić, Ivo (2017). Žeđ. U: Ivo Andrić, Andrić: Priče. Beograd: Laguna, 235-240.

Andrić, Ivo (2017). Bajron u Sintri. U: Ivo Andrić, Andrić: Priče. Beograd: Laguna, 241243.

Andrić, Ivo (2017). Deca. U: Ivo Andrić, Andrić: Priče. Beograd: Laguna, 244-247.

Andrić, Ivo (2017). Knjiga. U: Ivo Andrić, Andrić: Priče. Beograd: Laguna, 304-313.

\section{ЛИТЕРА Т У Р А}

Караулац, Мирослав (2006). Андрићево закопано благо. У: Андрићеве куле и градови. Нови Сад: Матица српска. 130-135.

Ковачевић, Милош (2000). Стилистика и граматика стилских фигура. Крагујевац: Кантакузин.

Николић, Милка (2012). Стилистика синтаксичких конструкција у приповеци Свадба Ива Андрића. У: Ivo Andrić - Literat und Diplomat im Schatten zweier Weltkriege (1925-1941) / Ivo Andrić - književnik $i$ diplomata u sjeni dvaju svjetskih ratova (1925-1941) (ur. B. Tošović). Beograd: Beogradska knjiga, 513524.

Пешикан, Митар, Јован Јерковић и Мато Пижурица (2014). Правопис српскога језика. Нови Сад: Матица српска.

Станојчић, Живојин, Љубомир Поповић (2004). Граматика српског језика. Београд: Завод за уџбенике и наставна средства.

Стевановић, Михаило (2004). Граматика српског језика. Београд: Предраг и Ненад. 
Ivanova, Irina (212). Interpunkcija proste rečenice u Andrićevim delima u periodu od 1925. do 1941. godine. U: Ivo Andrić - Literat und Diplomat im Schatten zweier Weltkriege (1925-1941)/Ivo Andrić - književnik $i$ diplomata u sjeni dvaju svjetskih ratova (1925-1941) ) (ur. B. Tošović). Beograd: Beogradska knjiga, 479-486.

Nikolić Novaković, Lidija (2017). Forenzička lingvistika: Primena metoda forenzičke lingvistike $u$ kriminalističkim istragama pretnje. Banjaluka: Evropski defendologija centar za naučna, politička, skonomska, socijalna, bezbjedonosna, sociološka i kriminološka istraživanja.

Olsson, John. (2010). Forenzička lingvistika (prev. Marijana Javornik Čubrić i Tomislav Sočanac). Zagreb: Nakladni zavod Globus.

Stanojčić, Živojin (1967). Jezik i stil Iva Andrića (Funkcije sinonimskih odnosa). Beograd: Filološki fakultet u Beogradu. 
Jovana Prokopijević

THE ATTRIBUTION OF I. ANDRIC'S AUTHORSHIP IN DISPUTED ARTICLES PUBLISHED IN THE MAGAZINE SVESKE PUBLISHED BY IVO ANDRIĆ'S ENDOWMENT (NUMBERS 16 AND 17)

Summary

The subject of this research is to determine I. Andric's authorship in the disputed articles published in the magazine Sveske published by Ivo Andrić's Endowment by determining linguistic and stylistic markers. The paper analyses the syntactic level of language in the questioned and known texts by Ivo Andrić. The aim of this work is to determine the similarities and differences in the language and style of known Andrić's texts and questioned manuscripts published in the journal, and to give an opinion on the possibility of Ivo Andrić's authorship in the disputed texts. The research is based on the material excerpted from six disputed and eight known texts. The method is the analysis of stylistic markers that identify an author and give us information about him, his language and style. The perception and analysis of the material give us a clear picture of Ivo Andrić's language and style as well as the language and style of the disputed texts. Their comparison casts light on the issue of Andrić's authorship in the disputed texts.

KEYWORDS: forensic linguistics, determining authorship, linguistically and stylistic markers, controversial manuscripts, style

Мср Јована Прокопијевић Филозофски факултет, Универзитет у Новом Саду Одсек за српски језик и лингвистику Република Србија jovana.prokopijevic@outlook.com 
